\title{
Author Correction: End-Permian extinction amplified by plume-induced release of recycled lithospheric volatiles
}

Michael W. Broadley, Peter H. Barry (1), Chris J. Ballentine (D), Lawrence A. Taylor and Ray Burgess

Correction to: Nature Geoscience https://doi.org/10.1038/s41561-018-0215-4, published online 27 August 2018.

In the version of this Article originally published, refs ${ }^{28-31}$ were listed in the wrong order, resulting in the citations in the main text being incorrect. The citations and reference list have now been updated in the online versions; the corrected order is shown below.

\section{References}

28. Aiuppa, A. et al. Emission of bromine and iodine from Mount Etna volcano. Geochem. Geophys. Geosyst. 6, Q08008 (2005).

29. Ross, P.-S. et al. Mafic volcaniclastic deposits in flood basalt provinces: a review. J. Volcanol. Geotherm. Res. 145, 281-314 (2005).

30. Millard, G. A., Mather, T. A., Pyle, D. M., Rose, W.I. \& Thornton, B. Halogen emissions from a small volcanic eruption: modeling the peak concentrations, dispersion, and volcanically induced ozone loss in the stratosphere. Geophys. Res. Lett. 33, L19815 (2006).

31. Black, B. A., Elkins-Tanton, L. T., Rowe, M. C. \& Peate, I. U. Magnitude and consequences of volatile release from the Siberian Traps. Earth Planet. Sci. Lett. 317, 363-373 (2012).

\section{Publisher Correction: Global-scale evidence for the refractory nature of riverine black carbon}

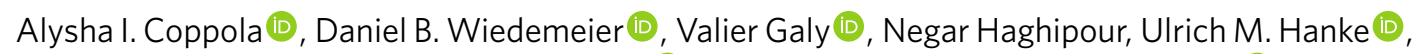
Gabriela S. Nascimento, Muhammed Usman (D), Thomas M. Blattmann, Moritz Reisser (D), Chantal V. Freymond,

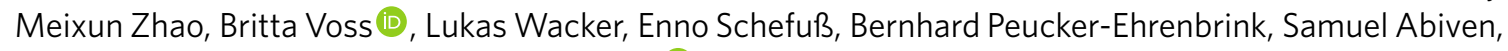
Michael W. I. Schmidt and Timothy I. Eglinton (D)

Correction to: Nature Geoscience https://doi.org/10.1038/s41561-018-0159-8, published online 9 July 2018.

In the version of this Article originally published, the units of the $x$ and $y$ axes in Fig. 3a were incorrectly given as ' $\mathrm{mg} \mathrm{km}^{-2} \mathrm{yr}^{-1}$ '; the correct units are ' $\mathrm{Mg} \mathrm{km}^{-2} \mathrm{yr}^{-1}$.' These errors have now been corrected in the online versions.

Published online: 9 October 2018

https://doi.org/10.1038/s41561-018-0252-z 